\title{
Do Socioeconomic Status (SES) Affect Students' Higher Education Attendance and Education Expectation: A Survey Based on Cross-Cultural Comparison
}

\author{
Jiarui Gao ${ }^{1, a, \dagger,{ }^{*}}$ Qianqian Chen ${ }^{2, b, \dagger}$ Qing Wang ${ }^{3, c, ~}{ }^{\circ}$ Mengfan $\mathrm{Guo}^{4, \mathrm{~d}, \dagger}$ \\ ${ }^{1}$ Faculty of Arts and Social Sciences, University of Sydney, Sydney, New South Wales 2050, Australia \\ ${ }^{2}$ Class of Liberal Arts and Sciences, University of Connecticut, Storrs, CT, 06269, US \\ ${ }^{3}$ School of Art and Social Science, University of Nottingham, Nottingham, UK. \\ ${ }^{4}$ School of Foreign languages, Hefei University of Technology, Xuancheng, China

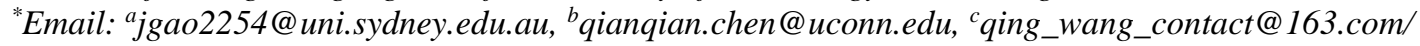 \\ dgmf@mail.hfut.edu.cn \\ These authors contributed equally.
}

\begin{abstract}
Generally, socioeconomic status (SES) is associate with family income, parental education and parental occupation, which affects students' academic development. In this paper, we investigate the effects of SES on education expectation from the perspective of cultural background. Specifically, the cultural differences between White American students and Chinese students have been analysed. In addition, the relationship between SES and education expectation among Chinese college students is evaluated. The data of Chinese college students are collected from a sample of 57 male and 99 female (between the ages of 15 to 22) based on online questionnaires. Their family income, parental education, parental occupation, students' possibility to enter higher education, and students' educational expectancy are classified in the questionnaires. As for white American culture, this study utilized a mixed-method to analyze 7 related articles and exploit the data. It is found that there's no significant positive relationship between SES and higher education attendance or education expectations among Chinese students. In fact, Chinese students from all SES have relatively high willingness and expectation to enter higher education. With regard to White American students, the family income, parental education and parental occupation significantly relate to their higher education attendance. Besides, in order to explain the phenomenon, social awareness about equal education opportunities were also discussed with corresponding implications. The cross-cultural comparison of beliefs, attitudes and behaviours that result in students' higher education attendance and Education Expectation will help better understanding students' development.
\end{abstract}

Keywords: Chinese college students, White American, education expectation, cultural differences, socioeconomic status

\section{INTRODUCTION}

Low Socioeconomic Status (SES) often associates with inequalities in accessing resources, including economic resources (e.g. salary and occupation), social resources (e.g. education, health care) and psychological resources (e.g. social networks and connections) [1, 2]. Previous literature indicates that SES could significantly affect the individual's personality and behaviour according to one's background [3]. Besides, it is consistently demonstrated that Socioeconomic Status backgrounds could influence students' behaviour in view of family systems and social standings, especially for the possibility to enter higher education [4]. According to the data collected from U.S. Census Bureau [5], young adults from the highest family income quartile would be considerably more likely to gain a bachelor's degree before age of 24 than the lowest quartile case [6]. Contemporarily, it's common sense that Socioeconomic Status (SES) has a significant effect on one's opportunity to succeed in higher education. However, such a relationship under Chinese circumstances has yet to be verified so far. In this paper, we choose the Chinese students from age 15 to 22 as the background and investigate the SES effects on their higher education attendances. 


\subsection{Differences of College Applying}

In order to examine the Socioeconomic barriers, it is necessary to understand each culture's economic obstacles primarily. In America, besides qualified test scores (e.g., SAT and/or ACT Scores if not TestOptional), high school transcript(s) and teacher recommendation letter are requested. According to the Coleman Report, which analyzed the inequality of educational opportunities in the U.S., family status in SES had the most significant influence on individuals' academic achievement. However, the score in the Chinese National College Entrance Examination is the only consideration to determine the level and types of higher education institutions the students study in. Particularly, college entrance examination scoring, as the only indicator, plays the central role in talent selecting the system to ensure the equality of opportunities. The successful enrollment in higher education, as a research independent variable, has a significant contribution to both student academic performance, graduate employment and career development [1]. Hence, cultural differences took a huge role in discussing higher education attendance.

\subsection{SES and Higher Education Attendance in China}

According to Chen's study. [7], high education is an important link for realizing equality of education and society. The analysis of low SES (socioeconomics) students provides a better understanding to improve educational opportunities for policymakers, educators and the public. Other authority, for example, the Council for Opportunities in Education (COE) could provide sufficient funding to poor financial students which encourages more low SES students to participate in higher education [6]. Besides, parents' situation has a significant influence on students throughout college. For instance, the information channel, one of the most important factors in parents' occupation, has both positive and negative impact on students' college choices [8]. In this paper, the accessibility of information will be searched and investigated for both U.S. and China. Based on China's education tracking survey data, rural parents' education level has a positive impact on family education expectation. In addition, social mobility expectation significantly improves family education expectation. Family education expectation will be higher for those with worse economic condition. Considering these interrelated factors, valuable suggestions are given for the sake of assisting low-SES families to conquer the barrier between the family and the offspring's education.

\subsection{SES and Higher Education Attendance in America}

Students' SES will be discussed as potential factors for higher education attendance in the U.S. through cultural differences. The college cost is extremely high and rising by years in the U.S, students have to depend on parents' support or students loan [9]. Unfortunately, there is a difficult chasm for low SES family to cross between the family income and the possibility for higher education. According to Houle's article. [9], students coming from low SES family take higher risks to pay off their student loan debt burdens than students with high-SES status due to the lack of resources from their parents. In other words, taking on student loans for college tuition is challenging for students in the low-SES family because of the low income and level of educational experiences as well as general occupations. Thus, the decisions about whether or not to enter higher education will be a more tough choice. Relatively low parental occupation corresponds to inferior status and prestige, with low family income. Thereby, there is no guarantee of stable or even highquality materials and resources for their children. Different from Chinese culture, for white Americans, there is no proportional relationship between parent's education level and family education expectation.

From the Bureau of Labor Statistics (BLS) and U.S. Census Bureau, $91 \%$ and $93 \%$ of Asian students in families with a relatively high level of income (the third and fourth income quartile) prefer to continue entering college after graduating from high school compared to others [10]. In view of the research conducted on SES for white Americans, more correlating studies are expected for cultural differences to make further investigation (e.g., Chinese college students). Moreover, from Chen's empirical study [7], higher income, parents' education and better occupation lead to higher-level offspring education in China. After stating the possible factors for Chinese students' higher education attendance, the hypothesis has been proposed that there's a positive relationship between students' SES and the possibility of entering higher education among Chinese college students.

\subsection{Purpose of the Study}

This article utilizes mixed methods to present the relationship between SES and higher education among Chinese college students and American students. Looking back to these considerations, we anticipated that the relationship between SES and higher education attendance may vary in China and America. The purpose was to further check the relationship between SES and Students education development in different cultural background (e.g., China \& U.S.). It was hypothesized that there is a positive relationship between SES and students' possibilities to enter higher education and education expectation among Chinese college students. 


\section{METHOD}

\subsection{Participants and Procedure}

For Chinese culture, we collected data from 156 students in total averagely aged 18.2756 (among 15 to 22 years old), including 57 male and 99 female participants who are living in China. The domain issues in selecting participants were geographic diversity and all SES availability to satisfy the representative nature of results. This study will obtain approval from the institutional review board and the parents of the participants, as well as obey the principles in the schools of the participants. The questionnaire is finished online with measurement focused on family income, parental education, parental occupation, students' possibility to enter higher education, and students' educational expectancy. There is no compensations and payment budget in our research. For American culture, we analyzed a large number of journals and finally screened out 7 useful articles to make comparisons with the measure taken in China.

\subsection{Measures}

\subsubsection{Family Income}

To identify students from which levels of family financial status, the scale (see Table 3) was designed and applied based on the data of the National Bureau of Statistics of China (NBSC) [11]. According to the NBSC [11], the average capita family income in China is 15666 yuan in the first half-year of 2020. We used 15666 yuan as the average family income $(50 \%)$ to dope out the remaining intervals of our scale. Inspired by the idea of Li and modify the Kuppuswamy SES scale [12-14], we regard the approximate percentage of $20 \%$ to categorize 5 different financial levels by average family income per month in Chinese Yuan: less than 7833 is the low income (scores 1), 7834 to 15666 is the lower middle income (scores 2), 15667 to 23499 is middle income (scores 3), 23500 to 31322 is higher-middle income (scores 4), and higher than 31322 is high income (scores 5). Participants indicated levels of family income per month following these five intervals with different scores.

\subsubsection{Parental Education}

Parental education is measured by Kuppuswamy Socio-economic Scale [13, 14], an effective scale for figuring out SES in participants. The Kuppuswamy SES scale analyzes the total monthly income of the family in Rupee, the occupation and education of the head of the family. Upgrading this Kuppuswamy SES scale, we divided family social status with total scores into five parts, ranging from 0 to 22 (see Table 9). Each family social status corresponds to a different score segment: less than 5 is the lower class, 5 to 10 is the upper lower class, 10.5 to 15 is lower middle class, 15.5 to 20 is upper middle class, and 20.5 to 22 is upper class. Higher scores denote the higher social status they are in. Applying to the Chinese educational system, we modified the Kuppuswamy SES scale by providing 7 different education backgrounds with corresponding scores (see Table 5): (1) Illiterate, (2) primary school certificate, (3) middle school certificate, skilled workers school certificate, vocational-technical school certificate, vocational middle school certificate, (4) high school certificate, vocational high school certificate, polytechnic college diploma, technician college diploma, (5) specialized secondary school certificate, secondary normal school certificate, higher professional school certificate, intermediate or diploma, (6) graduate, and (7) profession or honours. Similarly, the higher score represents the higher education background of their parents.

\subsubsection{Parental Occupation}

We also applied and modified the Kuppuswamy Socio-economic Scale [13, 14] to measure parental occupation. Our scale (see Table 7) classifies the occupation of the head of the family into 10 kinds of scores: unemployed (1), elementary occupation (2), plant $\&$ machine operators and assemblers (3), craft \& related trade workers (4), skilled agricultural fishery workers (5), skilled workers and shop \& market sales workers (6), clerks (7), technicians and associated professionals (8), professionals (9), and legislators, senior officials \& managers (10). High scores refer to the higher levels of occupation their parents have.

\subsubsection{The possibility for students to enter higher education}

The scores of the students' willingness to enter higher education and their educational expectancy based on Table 13 and 15: completely unwilling to (0), not willing to (1), relatively not willing to (2), neutral (3), relatively willing to (4), willing to (5), completely willing to (6) in Table 13; middle school certificate (1), vocationaltechnical high school (2), high school certificate (3), junior college certificate (4), intermediate or diploma (5), graduate, professions or honours (6) in Table 15. The higher scores of their willingness and their expectancy indicate the higher possibility that they will enter higher education in the future.

\subsubsection{Data Analysis}

In our analysis of Chinese culture, the descriptive statistics were provided on SES according to the several scales introduced above and summarized in tables in the result section. Subsequently, the relationships between SES and students' possibility to enter higher education and their educational expectancy were explored. As for American culture qualitative analysis, we categorized the 
7 journals according to their topic, author, and study groups, the reference of group race (yes/no) and result classified. Then, these information was summarized in a table in the result section to analyze and compare with the data of Chinese culture.

\section{RESULTS}

\subsection{Chinese Culture: Quantitative Results}

With regard to Chinese culture, several tables were given to present and compare the results of our online questionnaire. Table 1 introduces the socio-demographic features of our 156 samples. SES is related to family income, parental education and parental occupation, shown in Table 2, 4, 6. It was divided into 5 levels and evaluated in Table 8, which are lower class, upper lower class, lower middle class, upper middle class, and upper class. Our research summarized the average scores for statistics description of SES in Table 10 and analyzed the relationship between SES and the willingness for students to enter higher education and students' educational expectancy in Table 11.

\subsubsection{The statistical and descriptive data of SES}

Data in Table 2, 4, 6 calculates the average scores and percentage of family income, parental education, and parental occupation of our participants according to the scales in Table 3, 5, 7. Table 10 compares the average scores of these factors and SES.

Table 2 indicates that a relatively large proportion of the sample family receives less than 23500 yuan $(67.95 \%)$ total monthly income with an average score of 2.8462 . Table 4 shows that approximately half of the parents have received a high level of education, effectively strengthening their SES. Table 6 presents that it is the most common for parents to engage in elementary occupations. We calculate the average scores of participants' paternal and maternal education as well as the average scores of their occupation to acquire the final scores that classify their SES. Table 8 lists the total scores for each participant and categorizes them into their corresponding SES according to Table 9. These results indicate that the SES of Chinese families mainly distributes in the upper lower class to upper-middle class. Table 10 points out that the average total score to classify Chinese families' SES is 12.3716, belonging to the lower middle class.

Table 1: Socio-demographics of samples

\begin{tabular}{|c|c|c|c|c|}
\hline \multirow{2}{*}{\multicolumn{2}{|c|}{ Socio-demographics }} & Gender & & \\
\hline & & Male $\mathrm{n}$ (with\%) & Female n (with\%) & $\begin{array}{l}\text { Total } n \\
\text { (with\%) }\end{array}$ \\
\hline \multicolumn{2}{|c|}{ Gender $(n=156)$} & 57 (36.54\%) & $99(63.46 \%)$ & $156(100 \%)$ \\
\hline \multirow{8}{*}{$\begin{array}{l}\text { Age (years) } \\
(n=156)\end{array}$} & 15 & $3(1.92 \%)$ & $2(1.28 \%)$ & $5(3.21 \%)$ \\
\hline & 16 & $3(1.92 \%)$ & $5(3.21 \%)$ & $8(5.13 \%)$ \\
\hline & 17 & $9(5.77 \%)$ & 27 (17.31\%) & $36(8 \%)$ \\
\hline & 18 & $15(9.62 \%)$ & $33(21.15 \%)$ & $48(30.77 \%)$ \\
\hline & 19 & $12(7.69 \%)$ & $12(7.69 \%)$ & $24(15.38 \%)$ \\
\hline & 20 & $12(7.69 \%)$ & $12(7.69 \%)$ & $24(15.38 \%)$ \\
\hline & 21 & $3(1.92 \%)$ & $3(1.92 \%)$ & $6(3.85 \%)$ \\
\hline & 22 & $0(0 \%)$ & $5(3.21 \%)$ & $5(3.21 \%)$ \\
\hline \multirow{4}{*}{$\begin{array}{l}\text { Geographical } \\
\text { Distribution } \\
\quad(n=156)\end{array}$} & First-tier city & $25(16.03 \%)$ & 23 (14.74\%) & $48(30.77 \%)$ \\
\hline & Secondary city & $20(12.82 \%)$ & $63(40.38 \%)$ & $83(53.21 \%)$ \\
\hline & Third-tier city & $6(3.85 \%)$ & $8(5.13 \%)$ & $14(8.97 \%)$ \\
\hline & Fourth-tier city & $4(2.56 \%)$ & 7 (4.49\%) & $11(7.05 \%)$ \\
\hline
\end{tabular}


Table 2: Total monthly family incomes (unit: RMB yuan)

\begin{tabular}{cccccc}
\hline & Low income & $\begin{array}{c}\text { Lower-middle } \\
\text { income }\end{array}$ & $\begin{array}{c}\text { Middle } \\
\text { income }\end{array}$ & $\begin{array}{c}\text { Higher-middle } \\
\text { income }\end{array}$ & High income \\
\hline Family income range & $<7833$ & $7834-15666$ & $\begin{array}{c}15667- \\
23499\end{array}$ & $23500-31322$ & $>31322$ \\
Number of & 28 & 55 & 23 & 13 & 37 \\
participants & 17.95 & 35.26 & 14.74 & 8.33 & 23.72 \\
$\begin{array}{c}\text { Percentages (\%) } \\
\text { Score }\end{array}$ & 1 & 2 & 3 & 4 & 5 \\
Average Score & & & 2.8462 & & \\
\hline
\end{tabular}

Table 3: Scale for categorizing total monthly family incomes (unit: RMB yuan)

\begin{tabular}{|c|c|c|c|c|c|}
\hline & Low income & $\begin{array}{l}\text { Lower- } \\
\text { middle } \\
\text { income }\end{array}$ & $\begin{array}{l}\text { Middle } \\
\text { income }\end{array}$ & $\begin{array}{l}\text { Higher- } \\
\text { middle } \\
\text { income }\end{array}$ & High income \\
\hline $\begin{array}{l}\text { Family income } \\
\text { range }\end{array}$ & $<7833$ & $7834-15666$ & $\begin{array}{l}15667- \\
23499\end{array}$ & $\begin{array}{c}23500- \\
31322\end{array}$ & $>31322$ \\
\hline $\begin{array}{l}\text { Approximate } \\
\text { percentage of } \\
\text { sample (\%) }\end{array}$ & 20 & 20 & 20 & 20 & 20 \\
\hline Scores & 1 & 2 & 3 & 4 & 5 \\
\hline
\end{tabular}

Table 4: Parental education

\begin{tabular}{cccc}
\hline Parental Education & Numbers of participants & Percentages (\%) & Scores \\
\hline Illiterate & 0 & 0 & 1 \\
Primary school certificate & 0 & 0 & 3 \\
Middle school certificate & 32 & 20.52 & 3 \\
$\begin{array}{c}\text { Skilled workers school } \\
\text { certificate }\end{array}$ & 1.5 & 0.97 & 3 \\
$\begin{array}{c}\text { Vocational-technical school } \\
\text { certificate }\end{array}$ & 3.5 & 2.24 & 3 \\
\hline $\begin{array}{l}\text { Vocational middle school } \\
\text { certificate }\end{array}$ & 1 & 0.64 & \\
\hline
\end{tabular}




\begin{tabular}{lccc}
\hline $\begin{array}{c}\text { High school certificate } \\
\text { Vocational high school } \\
\text { certificate }\end{array}$ & 24 & 15.38 & 4 \\
$\begin{array}{c}\text { Polytechnic college } \\
\text { diploma }\end{array}$ & 7.5 & 4.81 & 4 \\
$\begin{array}{c}\text { Technician college diploma } \\
\text { Specialized secondary } \\
\text { school certificate }\end{array}$ & 1 & 2.56 & 4 \\
$\begin{array}{c}\text { Secondary normal school } \\
\text { certificate }\end{array}$ & 5 & 0.64 & 5 \\
$\begin{array}{c}\text { Higher professional school } \\
\text { certificate }\end{array}$ & 2 & 3.21 & 5 \\
Intermediate or diploma \\
Graduate
\end{tabular}

Table 5: Scale for categorizing parental education

\begin{tabular}{cc}
\hline Paternal / Maternal education & Scores \\
\hline Illiterate & 1 \\
Primary school certificate & 2 \\
Middle school certificate & 3 \\
Skilled workers school certificate & 3 \\
Vocational-technical school certificate & 3 \\
Vocational middle school certificate & 3 \\
High school certificate & 4 \\
Vocational high school certificate & 4 \\
Polytechnic college diploma & 4 \\
Technician college diploma & 4 \\
Specialized secondary school certificate & 5 \\
Secondary normal school certificate & 5 \\
Higher professional school certificate & 5 \\
Intermediate or diploma & 5 \\
Graduate & 6 \\
Profession or Honours & 7 \\
\hline
\end{tabular}

Table 6: Parental occupation

\begin{tabular}{cccc}
\hline Parental Occupation & Number of participants & Percentages (\%) & Scores \\
\hline Unemployed & 14 & 8.97 & 1 \\
Elementary occupation & 47.5 & 30.45 & 2 \\
Plant \& machine operators and & & & 3 \\
assemblers & 12.5 & 8.01 & 4 \\
Craft \& related trade workers & 4 & 2.56 & \\
\hline
\end{tabular}




\begin{tabular}{|c|c|c|c|}
\hline $\begin{array}{c}\text { Skilled agricultural \& fishery } \\
\text { workers }\end{array}$ & 5 & 3.21 & 5 \\
\hline $\begin{array}{l}\text { Skilled workers and shop \& } \\
\text { market sales workers }\end{array}$ & 5.5 & 3.53 & 6 \\
\hline Clerks & 18 & 11.54 & 7 \\
\hline $\begin{array}{c}\text { Technicians and associate } \\
\text { professionals }\end{array}$ & 10.5 & 6.73 & 8 \\
\hline Professionals & 18.5 & 11.86 & 9 \\
\hline $\begin{array}{l}\text { Legislators, senior officials \& } \\
\text { managers }\end{array}$ & 20.5 & 13.14 & 10 \\
\hline
\end{tabular}

Table 7: Scale for categorizing parental occupation $[13,14]$

\begin{tabular}{cc}
\hline Parental occupation & Scores \\
\hline Unemployed & 1 \\
Elementary occupation & 2 \\
Plant \& machine operators and assemblers & 3 \\
Craft \& related trade workers & 4 \\
Skilled agricultural \& fishery workers & 5 \\
Skilled workers and shop \& market sales workers & 6 \\
Clerks & 7 \\
Technicians and associate professionals & 8 \\
Professionals & 9 \\
\hline
\end{tabular}

Table 8: Socioeconomic status

\begin{tabular}{cccc}
\hline Scores & Number of participants & Percentage (\%) & Socioeconomic status \\
\hline$<5$ & 0 & 0 & Lower class \\
$5-10$ & 61 & 39.10 & Upper lower class \\
$10.5-15$ & 47 & 30.13 & Lower middle class \\
$15.5-20$ & 47 & 30.13 & Upper middle class \\
$20.5-22$ & 1 & 0.64 & Upper class \\
\hline
\end{tabular}

Table 9: Socio-economic status scale [13, 14]

\begin{tabular}{cc}
\hline Scores & Socioeconomic status \\
\hline$<5$ & Lower class \\
$5-10$ & Upper lower class \\
$10.5-15$ & Lower middle class \\
$15.5-20$ & Upper middle class \\
$20.5-22$ & Upper class \\
\hline
\end{tabular}

Table 10: The statistics and descriptive data of SES

\begin{tabular}{cc}
\hline $\begin{array}{c}\text { SES related factors } \\
\text { Average scores }\end{array}$ & Average scores \\
\hline $\begin{array}{c}\text { Total monthly family income } \\
\text { Parental education (average score of paternal \& } \\
\text { maternal education) }\end{array}$ & 2.8462 \\
\hline
\end{tabular}


Parental occupation (average score of paternal \& maternal occupation)

Socioeconomic status
5.1410

Lower middle class
3.1.2 The relationship between SES and the willingness for students to enter higher education and students' educational expectancy

We designed Table 13 and 15 to evaluate students' willingness to enter higher education and their educational expectancy with different scores. Data in Table 11 presents that Chinese students have strong willingnesses to enter higher education (average score of 5.9042) and a high level of educational expectancy (average score of 5.8493), especially in the SES of the upper lower class and upper class.

Table 12 and 14 lists the number of participants, percentage and average score of the willingness for students to enter higher education and students' educational expectancy. $95.51 \%$ of Chinese students are completely willing to enter higher education (Table 12) and $98.71 \%$ of Chinese students prefer to have an intermediate even higher educational background in the future (Table 14).

Table 11: The relationships between SES and the willingness for students to enter higher education and students' expectancy

\begin{tabular}{ccc}
\hline $\begin{array}{c}\text { SES classifications / } \\
\text { Average scores }\end{array}$ & $\begin{array}{c}\text { Students' willingness to } \\
\text { enter higher education }\end{array}$ & $\begin{array}{c}\text { Students' educational } \\
\text { expectancy }\end{array}$ \\
\hline Lower class & 0 & 0 \\
Upper lower class & 6 & 5.7377 \\
Lower middle class & 5.8509 & 5.7658 \\
Upper middle class & 5.7657 & 5.8936 \\
Upper class & 6 & 6 \\
Average & 5.9042 & 5.8493 \\
\hline
\end{tabular}

Table 12: Students' willingness to enter higher education

\begin{tabular}{cccc}
\hline $\begin{array}{c}\text { Students' willingness to } \\
\text { enter higher education }\end{array}$ & Number of participants & Percentage (\%) & Scores \\
\hline $\begin{array}{c}\text { Complete unwilling to } \\
\text { Not willing to }\end{array}$ & 0 & 0 & 0 \\
Relatively not willing to & 0 & 0 & 2 \\
Neutral & 2 & 1.28 & 3 \\
Relatively willing to & 1 & 1.28 & 5 \\
Willing to & 2 & 0.64 & 6 \\
Complete willing to & 149 & 1.28 & 5 \\
Average score & & 5.51 & \\
\hline
\end{tabular}


Table 13: Scale for the willingness of students to enter higher education

\begin{tabular}{cc}
\hline Students' willingness to enter higher education & Scores \\
\hline Complete unwilling to & 0 \\
Not willing to & 1 \\
Relatively not willing to & 2 \\
Neutral & 3 \\
Relatively willing to & 4 \\
Willing to & 5 \\
Complete willing to & 6 \\
\hline
\end{tabular}

Table 14: Students' educational expectancy

\begin{tabular}{cccc}
\hline $\begin{array}{c}\text { Students' educational } \\
\text { expectancy }\end{array}$ & Number of participants & Percentage (\%) & Scores \\
\hline $\begin{array}{c}\text { Middle school certificate } \\
\text { Vocational-technical high } \\
\text { school }\end{array}$ & 0 & 0 & 1 \\
$\begin{array}{c}\text { High school certificate } \\
\text { Junior college certificate }\end{array}$ & 1 & 0.64 & 3 \\
$\begin{array}{l}\text { Intermediate or diploma } \\
\text { Graduate, professions or } \\
\text { honours }\end{array}$ & 1 & 0.64 & 4 \\
$\begin{array}{c}\text { Students' educational } \\
\text { expectancy }\end{array}$ & 127 & 17.31 & 5 \\
Average score & Number of participants & Percentage $(\%)$ & 6 \\
\hline
\end{tabular}

Table 15: Scale for students' educational expectancy

\begin{tabular}{cc}
\hline Students' educational expectancy & Scores \\
\hline Middle school certificate & 1 \\
Vocational-technical high school & 2 \\
High school certificate & 3 \\
Junior college certificate & 4 \\
Intermediate or diploma & 5 \\
Graduate, professions or honours & 6 \\
\hline
\end{tabular}

Based on the above analyses, the hypothesis proposed earlier should be rejected, since there is no positive relationship between students SES and their educational expectations. These results reflect that Chinese family with different socioeconomic status all have relatively high willingness and expectation to enter higher education under any circumstances.

\subsection{American Culture: Qualitative Results}

As shown in Table 16, the impact of SES could be concluded in the following aspects. From the perspective of Gender, the female has a greater SES effect than the male in low SES family.[15] Nevertheless, intelligence has a greater impact than SES on university graduation for both genders [16,17]. It is consistent with Battle and Lewis's research, to be specific, the result confirms that the impact lost its power after entering higher education. In other words, it is worth studying SES factors before university study. The survey from Battle and Lewis reveals that SES impact only persists for a period of time. The advantages of high SES students will be lost in two years after enrollment [16]. The student perception for further education, in terms of student self-definition, is an essential subjective measure to provide a more nuanced, articulated, and comprehensive assessment of these 
complex, context-dependent variable [18]. The research implies that low SES students have a relatively low expectation of further study, i.e., influencing the choice of major in university. The result is in line with Salmelaro and Chmielewski's research which proves that only $28 \%$ of low SES students have the expectation for postgraduate studies. Major Choice with parent education from Salmelaro and Chmielewski survey also implies that there is a correlation between students major choice and parents education background. The students who tend to apply science, technology, engineering and math-retained (STEM) subject have a relatively high SES family among other applicants.[19] The researcher might predict that well-educated parents might provide insights for university major study. According to ten years followup survey, as the increasing of charted school in large school districts, parents from high SES family choose to keep their children in separate schools, allocating more education resources (e.g., taught by experienced and senior teachers). [20] This segregation not only leads to a further gap between high and low SES students but also have a negative influence on higher education enrollment. $[20,21]$

Other factors related to SES can also influence outcomes. To be specific, SES could affect Students psychological status. Students from poor family face significant psychological, academic and financial problems in college.[22, 23] According to the literature below, the geographic region also has to be considered. The U.S data were collected from different cities or states, which leads to data inconsistency. Education inequality from low SES family is the consequence of school resources limitation. [23, 24] Although the U.S government has legislated policies for low SES students, some university funding policies still create a barrier for these students. In addition, within the American cultural background, the racism related to the socioeconomic need to be considered. Whereas, the result of the National Education Longitudinal Study shows that SES

Table 16: Summary of findings for American Students' SES in Higher Education

\begin{tabular}{|c|c|c|c|c|}
\hline TOPIC & AUTHOR & RESULT & DATA & $\begin{array}{l}\text { REFERENCE } \\
\text { GROUP }\end{array}$ \\
\hline GENDER & $\begin{array}{l}\text { Sewell W } \\
\& \\
\text { Shah. V } \\
(1967) \\
{[15]}\end{array}$ & $\begin{array}{l}\text { More negative influence } \\
\text { on the female than male }\end{array}$ & $\begin{array}{l}7.9 \% \text { of low SES } \\
\text { verse } \\
60.9 \% \text { of female } \\
\text { students with high } \\
\text { SES. }\end{array}$ & $\begin{array}{l}\text { Students } \\
\text { in High \& Low SES } \\
\text { family } \\
(1957-1965)\end{array}$ \\
\hline $\begin{array}{l}\text { IMPACT } \\
\text { LENGTH }\end{array}$ & $\begin{array}{l}\text { Battle. J } \\
\& \\
\text { Lewis. M. } \\
(2002) \\
{[16]}\end{array}$ & $\begin{array}{l}\text { High SES students lose } \\
\text { advantages in university } \\
\text { study }\end{array}$ & $\begin{array}{l}2 \text { years after } \\
\text { university } \\
\text { enrollment }\end{array}$ & $\begin{array}{l}\text { U.S 12-grade high } \\
\text { school } \\
\text { Student }\end{array}$ \\
\hline $\begin{array}{l}\text { EDUCATION } \\
\text { PERCEPTION }\end{array}$ & $\begin{array}{l}\text { Rubin, L. } \\
\text { Et al. } \\
(2014) \\
{[18]}\end{array}$ & $\begin{array}{l}\text { Low SES student have } \\
\text { lower expectation } \\
\text { compared with high SES } \\
\text { student }\end{array}$ & $\begin{array}{l}28 \% \text { of low SES } \\
\text { students expect } \\
\text { postgraduate }\end{array}$ & $\begin{array}{l}\text { Students Perception } \\
\text { in High \& Low SES } \\
\text { family }\end{array}$ \\
\hline $\begin{array}{l}\text { MAJOR } \\
\text { CHOICE } \\
\text { (parent } \\
\text { education) }\end{array}$ & $\begin{array}{l}\text { Salmelaro, K. } \\
\& \\
\text { Chmielewski A. } \\
(2009) \\
{[19]}\end{array}$ & $\begin{array}{l}\text { High SES students who } \\
\text { choose to apply } \\
\text { academically } \\
\text { demanding subjects are } \\
\text { more likely to have highly } \\
\text { educated parents. }\end{array}$ & $\begin{array}{l}\text { The proportion in } \\
\text { STEM (science, } \\
\text { technology, } \\
\text { engineering and } \\
\text { math-retained) } \\
\text { applicants }\end{array}$ & $\begin{array}{l}\text { Students } \\
\text { in High \& Low SES } \\
\text { family } \\
(2015-2016)\end{array}$ \\
\hline $\begin{array}{l}\text { IMPACT } \\
\text { (from parent } \\
\text { occupation) }\end{array}$ & $\begin{array}{l}\text { Marcotte D. E. } \\
\& \\
\text { Dalane, K. } \\
(2019) \\
{[20]}\end{array}$ & $\begin{array}{l}\text { School segregation } \\
\text { between high \& low SES } \\
\text { family enlarges the gap for } \\
\text { university enrollment. }\end{array}$ & $\begin{array}{l}\text { The increasing } \\
\text { growth of Charter } \\
\text { School in the } \\
\text { largest school } \\
\text { district changed } \\
\text { education } \\
\text { Resources, } \\
\text { exacerbating SES } \\
\text { segregation among } \\
\text { public school } \\
\text { students in the } \\
\text { future. }\end{array}$ & $\begin{array}{l}\text { Students in High \& } \\
\text { Low SES family } \\
\text { (income-based) } \\
\text { for } 10 \text { years. } \\
(1995-2015)\end{array}$ \\
\hline
\end{tabular}


RACE

The US. National
Education
Longitudinal
Study

[16]

$\begin{array}{ll}\text { POLICY } & \text { Berg, G } \\ \& & (2016) \\ \text { FUNDING } & {[17]} \\ \text { POLICY } & \end{array}$

SES impact has three times important than race

Financial aids policies work against low- income students.

\begin{abstract}
White students
lose their

advantages after

high school 2 years

later.
\end{abstract}

Funding for higher
education has
primarily aided
students
from middle and
upper-class

African \& White American in 12grade

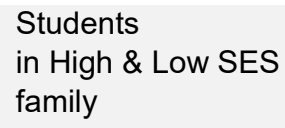
students.

the impact has three times important than racism. On account of the single race in china, racism is not discussed in Chinese cultural background. [17]

In conclusion, SES has positive correlations with students in the U.S, especially from the aspects of education expectation, parents' education and occupation. Students with high SES have more expectation of further education. Occupation and education of parents have an impact on students' major choices. SES impact loses power after university study.

\section{DISCUSSION}

Students from high SES families benefit from richer resources compared with students from low SES families and are more likely to get higher education in the U.S. while students from different SES families all have high education expectation and SES has no correlation with whether students get higher education or not in China.

\subsection{The relationship between SES and entering higher education}

According to our research, there is no significant correlation between SES and higher education for Chinese students. However, as for white American students, the positive relationship holds. Based on the research data, the following discussion is demonstrated.

\subsection{Chinese culture}

First, the Chinese have long been affected by traditional cultures, e.g., "All kinds are inferior, only reading high". Such a culture system leads to homogenous positive high expectations for different SES families. Besides, children are used to taking advice from their predecessors. As pointed out in Ref. [25], Confucian cultural circles pay attention to reading culture. Thus, the strong wind of shadow education and high college aspirations are the concentrated expressions of this educational fanaticism.

In addition, academic qualifications in global society are becoming more and more fierce [25]. With the deepening of reform and opening up following the socialist market economic system, China's rapid development has forced the increment of talents [26]. The Third Plenary Session of the Eighteenth Central Committee of the Communist Party of China pointed out that it is necessary to promote the modernization of the national governance system and governance capacity, which requires more talents to participate accordingly [27].

\subsection{American culture}

Primarily, the segregation of SES has led to changes in school enrollment through the findings in Table 7. High-income families choose to educate their kids in separate schools due to the growth of Charter School in the largest school district. Cohodes et al. studied a policy reform that allowed effective charter schools in Boston, Massachusetts to replicate their school models at new locations. Estimates based on randomized admission lotteries show that replication charter schools generate large achievements on par with those produced by their parent campuses. The average effectiveness of Boston's charter middle school sector increased after the reform despite a doubling of charter market share [28]. Therefore, the segregation of SES among public school students in the future has been exacerbated.

Furthermore, the characteristic of higher education management in developed countries is democratization. In the management mechanism of higher education in European and American countries, deliberative bodies are generally set up. These deliberation members will put forward more appropriate suggestions for the development and decision-making of higher education [29].

Last but not least, the United States adopts open education, which is embodied in three different aspects, which named the formulation of an open enrollment policy, the openness of existing campus venues and the openness of school-running concepts. American universities generally adopt the methods of recommendation, oral examination and written examination [30]. Compared with the way of recruiting 
students with only one exam, this more diversified way can involve more human factors. Material conditions still shape the common experience of university students (e.g., long distances commute, poor and unsafe transport, low wages and food insecurity [31]).

\subsection{Comparison between China and America}

From the perspective of the major selection, one survey in America implies that there is a correlation between students' choice of major and their parents' education. Applicants who tend to apply for STEM subjects have higher SES background than others $[18,19]$. There are also many Chinese who choose STEM subjects, but usually for other reasons. Chinese (and other Asians) are called "model ethnic minorities" by society, schools and media, forming a new stereotype. This virtually caused unequal evaluation standards and unrealistic expectations. As a consequence, it strengthened the social prejudice that they are naturally suitable for engaging in STEM subjects. On the one hand, these ideas create practical and potential obstacles to the career pursuit of Asian children, including the Chinese. On the other hand, they also force Asian ethnic groups and families to limit their expectations for the next generation to the fields recognized by mainstream society as suitable for them [32]. Chinese immigrant families hope that their children will find a stable job with a high salary through personal efforts. Moreover, they believe that they can gain a foothold in mainstream society via choosing practical subjects [32].

From the perspective of education expectation, a substantial portion of the SES effect operates through the impact of high school academic achievement and postsecondary education expectation [33]. For western students, research indicates that students from low SES families have low expectations of higher education [17]. However, another survey of 382 migrant children aged 10-14 in Beijing migrant children's school shows that family SES affects children's math scores through their educational expectations. Furthermore, subjective SES reduces the negative impact of low SES families on migrant children [34]. However, our research has not found the effects of different SES on specific subjects through educational expectation, which may be due to the lack of subjects' differentiation. Apart from that, there is a positive correlation between family background and university expectations in Korea and Singapore [25]. Nevertheless, according to our questionnaire survey, this correlation does not exist for Chinese students.

From the perspective of parents' educational background and occupation, it is predicted that welleducated parents offer help for students' study at universities for U.S. case $[18,19]$. With regard to Chinese students, fathers' educational attainment significantly affects graduates' CEE (College Entrance Examination) scores [1]. Besides, it is found that migrant parents will bring negative effects to the education of left-behind children to a certain extent [37].

From the perspective of policy, the American government grants students less directly. Instead, more funds are provided to students by means of loans [38]. Moreover, the core power of American higher education is the market mechanism, which has a great influence on American for-profit universities. The Communist Party of China has been committed to promoting poverty alleviation, in which education is the most important part. "Education for Poverty Alleviation", "China Education Modernization 2035", etc. increase the possibility of students obtaining higher education [39].

From the perspective of gender, SES affects females more than males in low SES families [15]. Family background indicators are differentially related to uptake for male and female students. Instead, parents' social class and education are larger predictors of choice than financial resources [35]. Women still lag behind men in terms of access to higher education, quality of education, etc. Gender difference in education is still an important practical problem [36].

\section{LIMITATIONS AND RESEARCH DIRECTIONS}

The effects of SES on Chinese students' access to higher education are in low agreement with our hypothesis. This is mainly because the scope of our data collection and the number of samples are limited. In this case, the data were not so comprehensive and unable to reflect the divergence of different SES families. Therefore, it leads to insufficient validation of the samples. Beyond that, students' cognition of themselves is not accurate and clear due to the subjectivity of the questionnaire. Our research directions are (a) obstacles to higher education for students with different SES family backgrounds, (b) the relationship between SES and the possibility of white American and Chinese College Students entering higher education, and (c) the feasible solutions to improve the possibility of obtaining higher education. The goal is to have a good command of the logic behind them, i.e., improve the possibility of students getting a higher education.

\section{CONCLUSION}

In summary, the effects of different SES families on students' possibility of obtaining higher education and education expectation are investigated. In quantifying research of Chinese students, all subjects showed a high willingness to get higher education. In other words, no positive relationship has been found between students' SES and their possibilities to enter higher education. In the qualitative study results of white American students, SES is positively correlated with students' access to higher education. After analyzing these results, 
corresponding feasible suggestions on existing problems are puts forward. Education is a fair, predictable and effective way for the members of the disadvantaged groups to achieve upward social mobility [32]. The influence of SES on students' access to higher education should be inhibited and reduced significantly.

\section{REFERENCES}

[1] Wen, D., Impacts of social economic status on higher education opportunity and graduate employment in China. Frontiers of Education in China, 1(3), 2006, pp. 426-438.

[2] Peverill, M., Dirks, M. A., Narvaja, T., Herts, K. L., Comer, J. S., \& McLaughlin, K. A., Socioeconomic status and child psychopathology in the United States: A meta-analysis of POPULATION-BASED STUDIES. Clinical Psychology Review, 3, 2020, pp. 101-933. https://doi.org/10.1016/j.cpr.2020.101933.

[3] Ostrove, J. M., \& Cole, E. R., Privileging class: Toward a critical psychology of social class in the context of education. Journal of Social Issues, 59, 2003, pp.677-692. https://doi.org/10.1046/j.00224537.2003.00084.x.

[4] Jury, M., Smeding, A., Stephens, N.M., Nelson, J.E., Aelenei, C., \& Darnon, C., The experience of low-SES students in higher education: psychological barriers to success and interventions to reduce social-class inequality. Journal of Social Issues, 73(1), 2007, $23 \quad$ - $\quad 41$. https://doi.org/10.1111/josi.12202.

[5] U.S. Census Bureau, A half-century of learning: historical statistics on educational attainment in the United States, 1940 to 2000. Washington, D.C.: U.S. Department of Commerce. U.S. Newswire, 2005.

[6] Cahalan, M. W., Perna, L. W., Addison, M., Murray, C., Patel, P. R., \& Jiang, N., Indicators of higher education equity in the United States: 2020 historical trend report. Washington, DC: The Pell Institute for the Study of Opportunity in Higher Education, Council for Opportunity in Education (COE), and Alliance for Higher Education and Democracy of the University of Pennsylvania (PennAHEAD), 2020.

[7] Chen, X., Who has more opportunities to attend college? - An empirical study of the strata distribution of different qualities of higher education opportunities in China. Chinese Education and Society, 48(3), 201-217, 2015. https://doi.org/10.1080/10611932.2015.1085769,
[8] Fang, W., \& Wang, S., Chines students' choice of transnational higher education in a globalized higher education market: A case study of W University. Journal of Studies in International Education, 18(5), 2014, pp. 475-494, https://doi.org/10.1177/1028315314523989.

[9] Houle, J., Disparities in debt: parents ' socioeconomic resources and young adult student loan debt. Sociology of Education, 87(1), 2014, 53

https://doi.org/10.1177/0038040713512213.

[10] Bureau of Labor Statistics (BLS), \& U.S. Census Bureau. Postsecondary Educational Opportunity (PEO) database. Indicators of higher education equity in the United States: 2020 historical trend report. Washington, DC: The Pell Institute for the Study of Opportunity in Higher Education, 2018.

[11] National Bureau of Statistics of China. Households' Income and Consumption Expenditure in the First Half Year of 2020. Press Release. [online] Available:

http://www.stats.gov.cn/english/PressRelease/2020 07/t20200716_1776358.html

[12] Li, W. Family Background, Financial Constraints and Higher Education Attendance in China. Economics of Education Review, vol.26, no.6, 2007, pp. 724-734. DOI: https://doi.org/10.1016/j.econedurev.2007.09.001

[13] Kuppuswamy, B., Manual of Socio-economic Status Scale (Urban). Delhi: Manasayan Publication, 1981.

[14] Saleem, S.M. Modified Kuppuswamy Socioeconomic Scale Updated for the Year 2020. Indian Journal of Forensic and Community Medicine, vol.7, no.1, 2020, pp.1-3. [online] Available:

https://www.researchgate.net/publication/34082898 5_Modified_Kuppuswamy_socioeconomic_scale_u pdated_for_the_year_2020

[15] Sewell, W., \& Shah, V. Socioeconomic Status, Intelligence, and the Attainment of Higher Education. Sociology of Education, 40(1), 1967, pp.1-23. https://doi.org/10.2307/2112184.Battle, J. \& Lewis, M. The Increasing Significance of Class: The Relative Effects of Race and Socioeconomic Status on Academic Achievement, Journal of Poverty, 2002, pp.21-35. https://doi.org/10.1300/J134v06n02_02.

[16] Battle, J. \& Lewis, M. The Increasing Significance of Class: The Relative Effects of Race and Socioeconomic Status on Academic Achievement, Journal of Poverty, 2002, pp.2135. https://doi.org/10.1300/J134v06n02_02. 
[17] Berg A.G. Low-income students and the perpetuation of inequality: Higher education in America. Second Edition. Routledge, 2016, pp.55.

[18] Rubin, M., Denson, N., Kilpatrick, S., Matthews, K., Stehlik, T. \& Zyngier, D. 'I Am Working-Class": Subjective Self-Definition as a Missing Measure of Social Class and Socioeconomic Status in Higher Education Research. Education Research, 2014. published online $19 \quad$ March https://doi.org/10.3102/0013189X14528373.

[19] Salmela-Aro, K.\& Chmielewski, A. Socioeconomic Inequality and Student Outcomes in Finnish Schools, 2019, pp.153. https://doi.org/10.1007/978-981-13-9863-6_9.

[20] Marcotte D, E.\& Kari, D. Socioeconomic Segregation and School Choice in American Public School. Education Research 0013189X1987971, 2019. https://doi.org/10.3102/0013189X19879714.

[21] Perna W, L. \& Marvin A. Titus. The Relationship between Parental Involvement as Social Capital and College Enrollment: An Examination of Racial/Ethnic Group Differences, The Journal of Higher Education, 2015, pp.485-518 http://dx.doi.org/10.1080/00221546.2005.11772296.

[22] Ed, Kincheloe. \& Steinberg, Shirley. Cutting Class: Socioeconomic Status and Education. Culture and Education Series. Rowman \& Littlefield Publishers, 2009, pp.71-79.

[23] Walpole, M. Socioeconomic Status and College: How SES Affects College Experiences and Outcomes. The Review of Higher Education, 27(1), 2003, pp.45-73. https://doi.org/10.1353/rhe.2003.0044.

[24] Mingat, A., Tan, J. Who Profits from the Public Funding of Education: A Comparison of World Regions. Comparative Education Review, 30(2), 1986, pp.260-270. https://doi.org/10.1086/446592.

[25] Wang, W., Dong, K., Are the University Expectations of Young People in Confucian Cultural Circles Still High? _ Based on the Analysis of PISA 2009-2018 in Korea and Singapore [J], Chinese Youth Research, 2020, pp. 100-108.

[26] Zhang, Y., Development Trend of the College Entrance Examination Over in the Past 40 Years, Journal of Shanxi Normal University (Philosophy and Social Science's Edition). Vol. 6 No. 4, 2017, pp. 5-11.

[27] Lei, Y., Wang, L., Analysis on the Evolution of Cultural Policy in the 70 Years of New China, Journal of Weinan Normal University, 2019, pp. 16-24.
[28] Cohodes, S. R., Setren, E. M., Walters, C. R., Can Successful Schools Replicate? Scaling Up Boston’ s Charter School Sector $\uparrow$, American Economic Journal: Economic Policy, 2021, pp. 138-167.

[29] Cao, J., Characteristics of Higher Education Management in Developed Countries and Its Enlightenment to China $[\mathrm{J}]$, Journal of Heihe University, 2018, pp.17-18.

[30] Lin, H., Research on the Adjustment of Discipline and Specialty Structure in Colleges and Universities [D], Xiamen: Xiamen University, 2006.

[31] Walker, M., \& Wilson-Strydom, M, Rural youth and access to higher education: Intersectional conversion factors, poverty and capabilities. Human Development and Capability Association annual conference, Cape Town, 2017.

[32] Zhou, M., Wang, J., Educational Expectations of Chinese New Immigrants and Their Challenges, Institutional Restrictions and Social Support Taking the United States and Singapore as Examples [J], Overseas Chinese History Studies, 2019, pp.1-9.

[33] Frempong, G., Ma, X., \& Mensah, J., Access to Postsecondary Education: Can Schools Compensate for Socioeconomic Disadvantage, Higher Education. Volume 63, Issue 1, 2012, pp. 19-32.

[34] Ren, Y., Huang, S, Family Socio-economic Status and the Academic Achievement of Migrant Children: the Role of Educational Expectation and Subjective Socio-economic Status, Summary of the 22nd Chinese psychological society, 2019.

[35] Mcmaster, N. C., Who Studies STEM Subjects at A Level and Degree in England? An Investigation into the Intersections Between Students' Family Background, Gender and Ethnicity in Determining Choice [J], British Educational Research Journal. Volume 43, Issue 3, 2017, pp.528-553.

[36] Zheng, L., Zhang, D, A Review of Economic Research on Gender Differences in Education in China [J], Essays on Women's Studies, 2013, pp. 112-119.

[37] Xiong, X., The Influence of Parents' Going Out to Work on the Education of Left-behind Children [D], Huazhong Normal University, 2018.

[38] Zhang, G., Wang, Y., Characteristics of American higher education and its enlightenment to Chinese higher education [J], Journal of Jinan Vocational College, 2020, pp.76-78.

[39] Zhang, P., Research on the Evolution of Socialist Education Policy with Chinese Characteristics [D], Lanzhou Jiaotong University, 2020. 